Jurnal Konstruksi Hukum | ISSN: XXXX | E-ISSN: XXXX Vol. 1, No. 1, September 2020 Hal. 214-219| Available online at https://www.ejournal.warmadewa.ac.id/index.php/jukonhum DOI: https://doi.org/10.22225/jkh.1.1.2123.214-219

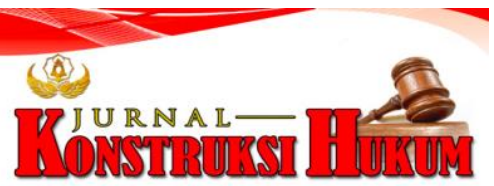

\title{
PERLINDUNGAN HUKUM TERHADAP KONSUMEN YANG MENGKONSUMSI DAGING AYAM TIDAK LAYAK JUAL DI PASAR BADUNG - BALI
}

\author{
Adinikum Keba Tunggu, I Nyoman Putu Budiartha, Ni Made Sukariyati Karma \\ Fakultas Hukum Universitas Warmadewa, Denpasar - Bali, Indonesia
}

\begin{abstract}
Abstrak
Perlindungan konsumen adalah instrumen hukum yang dibuat untuk melindungi dan memenuhi hak-hak konsumen sesuai dengan prosedur yang benar. Namun, sesuai dengan masalah yang ada di lapangan mengakibatkan kerugian bagi konsumen. Penelitian ini bertujuan untuk mengetahui perlindungan hukum bagi konsumen yang mengkonsumsi daging ayam tidak layak jual di Pasar Badung dan mengetahui upaya yang dilakukan oleh Pengawas Makanan dan Obat-obatan (BPOM) ketika penjualan daging ayam tidak cocok untuk dikonsumsi. Penelitian ini didesain dengan menggunakan pendekatan Hukum Empiris. Teknik pengumpulan data dalam penelitian ini yaitu menggunakan wawancara. Kemudian, data dianalisis dengan menggunakan teknik deskriptif kualitatif. Hasil penelitian ini menunjukan bahwa perlindungan hukum terhadap konsumen dalam hal terjadinya penjualan daging ayam yang tidak layak konsumsi di pasar Badung sudah diatur dalam Undang-undang Nomor 8 Tahun 1999 tentang Perlindungan Konsumen. Namun, berdasarkan data di lapangan konsumen banyak yang tidak mengetahui perlindungan hukum yang ada dikarenakan minimnya pengetahuan dan wawasan konsumen terkait dengan perlindungan hukum yang mereka miliki sehingga menyebabkan konsumen selalu dirugikan dengan tindakan pelaku usaha yang tidak pernah memberikan informasi yang benar jelas dan jujur. Kemudian, upaya yang dapat dilakukan Badan Pengawas Obat dan Makanan (BPOM) dalam hal terjadinya penjualan daging ayam yang tidak layak konsumsi adalah dengan cara melakukan inspeksi ke lapangan serta memberikan informasi dan edukasi langsung kepada konsumen dan pelaku usaha sehingga konsumen dan pelaku usaha lebih mengetahui jenis-jenis daging ayam tidak layak untuk di perdagangkan dan/at au di konsumsi oleh konsumen.
\end{abstract}

Kata Kunci: Daging ayam tidak layak jual; Konsumen; Perlindungan hukum

\begin{abstract}
Consumer protection is a legal instrument designed to protect and fulfill consumer rights in accordance with correct procedures. However, according to the problems in the field it results in losses for consumers. This study aims to determine the legal protection for consumers who consume unfit chicken meat in Badung Market and to find out the efforts made by the Food and Drug Administration (BPOM) when selling chicken meat is not suitable for consumption. This research was designed using an empirical law approach. The data collection technique in this research is to use interviews. Then, the data were analyzed using descriptive qualitative techniques. The results of this study indicate that the legal protection of consumers in the event of the sale of unfit for consumption chicken meat in the Badung market has been regulated in Law Number 8 of 1999 concerning Consumer Protection. However, based on data in the field, many consumers do not know about existing legal protections due to the lack of knowledge and insight of consumers regarding their legal protection, which causes consumers to always be disadvantaged by the actions of business actors who never provide true, clear and honest information. Then, the efforts that can be made by the Food and Drug Supervisory Agency (BPOM) in the event that the sale of chicken meat is not suitable for consumption is by conducting field inspections and providing information and education directly to consumers and business actors so that consumers and entrepreneurs know more about the types of chicken meat the type of chicken meat is not suitable for trade and/or consumption by consumers
\end{abstract}

Keywords: Legal Protetion; Consumer; Chiken meat unfit for consumption

\section{PENDAHULUAN}

Indonesia merupakan negara hukum berdasarkan ketentuan dalam Pasal 1 Ayat (3) UUD 1945 bahwa Negara Indonesia adalah negara hukum maka setiap Manusia mempunyai kebutuhan yang beragam seiring dengan peningkatan kesejahteraannya dan kedamaian masyarakat. Namun dalam memenuhi kebutuhan masyarakat lebih berhati-hati memilih produk yang aman apalagi para era globalisasi serba 
canggih produsen sering berlaku curang kepada konsumen demi mendapatkan keuntungan pribadi sebesar-besarnya serta pelaku usaha seringkali menyampingkan hak-hak konsumen seperti kenyamanan keamanan dan keselamatan. Pada saat hari raya permintaan pasar akan bahan makanan semakin meningkat terutama daging ayam konsumen harus cermat memilih daging ayam jangan mudah terpancing dengan harga murah karena para oknum nakal penjual daging ayam yang tidak layak konsumsi biasanya mereka seringkali berani memberikan harga lebih murah dari pada harga pasar pada umumnya biasanya ayam tiren sering dijumpai di pasar-pasar tradisional yang sistem penjualnya bebas tanpa pengawasan dari Balai Besar Badan Pengawas Obat dan Makanan (BPOM). Pengawasan daging ayam di pasar tradisional hanya dilakukan sekali dalam 5 tahun oleh pihak berwajib (Sunyoto, 2018:30). Dengan demikian, konsumen lebih cermat dalam memilih bahan makanan. Pemerintah pusat telah mengeluarkan Undang-Undang Nomor 8 tahun 1999 tentang perlindungan konsumen agar para konsumen memiliki perlindungan hukum yang kuat.

Beberapa penelitian terkait dengan daging yang layak konsumsi serta perlindungan bagi konsumen telah banyak diteliti sebelumnya seperti Barkatullah \& Djumadi (2018); Ramadhan \& Umar (2016) mengatkan bahwa perlindungan hukum bagi konsumen terhadap peredaran daging ayam di pasar tradisional belum belum maksimal sesuai yang diatur di dalam Undang-Undang Perlindungan Konsumen karena pengawasan yang hanya pada pemeriksaan dokumen. Oleh karena itu, diperlukan sosialisasi dan melakukan inspeksi mendadak cukup mampu utuk meminimalisasi peredaran daging ayam yang tidak layak di pasar tradisional. Kemudian, Kamilaris, Fonts, \& Prenafeta-Boldó (2019); Pham \& Dinh (2020); Torrico et al. (2018); Wansink (2004); Zhang, Li, \& Bai (2020) membahasa tentang kelayakan daging dan perlindungan hukum bagi konsumen. Berdasarkan latar belakang masalah di atas, maka penelitian yang baru ini bertujuan untuk mengetahui perlindungan hukum terhadap konsumen yang mengkonsumsi daging ayam tidak layak dijual di pasar Badung dan mengetahui upaya yang dilakukan oleh Balai Pengawas Obat dan Makanan (BPOM) dalam hal terjadinya penjualan daging ayam tidak layak konsumsi.

\section{METODE PENELITIAN}

Penelitian ini didesain dengan menggunakan tipe penelitian hukum empiris dengan pendekatan sosiologis hukum. Ada dua sumber data penelitian ini yaitu data primer dan sekunder. Selain itu, lokasi penelitian dalam kajian ini dilakukan di Pasar Badung-Bali terkhusus untuk produk hukum Perlindungan Hukum Konsumen untuk mengetahui Konsumen Yang mengkonsumsi daging ayam Tidak Jual di pasar Badung-Bali. Data primer diperoleh melalui wawancara hukum primer serat peraturan undang-undang, sedangkan data sekunder dikumpulkan dari bahan kepustakaan, media internet dan literature atau buku-buku. Setelah data terkumpul, kemudian, dianlisis dan dideskripsikan melalui kata-kata serta disertakan fakta yang ditemukan dilapangan.

\section{HASIL DAN PEMBAHASAN}

\section{Perlindungan Hukum terhadap Konsumen yang Mengkonsumsi Daging Ayam Tidak Layak Dijual di Pasar Badung}

Pada perlindungan hukum menjadi suatu susunan perlindungan yang paling penting peranannya sesuai pada tujuannya maka aturan sebagai sarana terpenting didalam akomodasi kepentingan secara langsung bagi hak hak manusia secara komprehensif. Dari hal diatas aturan berada pada kekuatan hierarki Indonesia dapat diakui secara resmi oleh negara sehingga kemudian dapat dijalankan secara permanen. Keamanan konsumen menjadi tujuan utama untuk melakukan terkait dengan usaha demi masyarakat sejahtera dalam kehidupan peradaban manusia terhadap pesatnya transaksi perdagangan pada era modern. Perhatian dari badan hukum perlindungan konsumen sekarang bukan hanya di negara ini namun perhatian ini sudah mendunia. Pandangan yang beda dengan perlindungan melalui badan institusi lainnya seperti perlindungan ekonomi serta terhadap perlindungan politik bersifat temporer atau cuma-cuma.

Arti konsumen secara yuridis sudah disimpan diperaturan perundang-undangan misalnya Undang-undang nomor 8 Tahun 1999 Tentang UUPK lebih jelas dijelaskan pada Pasal 1 menentukan bahwa Konsumen merupakan badan pengguna barang dan/atau jasa dapat disiapkan untuk seseorang dari segi kepentingan pribadi keluarga serta makhluk hidup lain dan tidak ada izin jualbeli (Miru \& Yodo, 2008:1). 
Dalam hidup yang layak tentu negara memerlukan keamanan hukum demi kenyamanan benda atau barang kemudian diberikan kepada masyarakat kadang barang datang sangat beda jauh dengan perjanjian awal. Syarat-syarat berlakunya aturan hukum untuk melindungi segenap hak seseorang tidak ada kebenaran dan kepastian norma aturannya (Susanto, 2008:).

1. Asas dan Tujuan Hukum Perlindungan Konsumen

Paul Scholten mengatakan bahwa asas merupakan arahan yang dapat memberikan pada penilaian yang sifatnya mempunyai etis hukum. Dan juga H.J. Hommes menjeleskan asas aturan itu bukan norma aturan lebih nyata tapi bagi pokok yang paling umum merupakan arahan berlakunya aturan hukum. Sama halnya dengan penemuan diatas diteruskan oleh Rahardjo (1980) bahwa asas aturan itu mempunyai kepastian yang etis bagaikan sarana atau penghubung produk aturan dan impian manusia dan penglihatan masyarakat yang sangat etis (Sasongko, 2005:36).

1) Asas kebenaran adalah untuk mencari kebenaran demi hak dan kewajiban masyarakat pada umumnya kebenaran juga memberikan kesempatan bagi penjual dan pembeli kemudian dapat diperoleh hak serta kewajiban yang seadil-adilnya (Amirrudin \& Asikin, 2012)

2) Asas kepastian hukum Diberlakukan Bagi penikmat barang atau jasa yang layak dipakai atau dikonsumsi dan menaati pada aturan undang-undang yang berlaku supaya memperoleh keadilan hukum dalam pelaksanaan melindungi hak-hak konsumen serta negara menjamin kepastian hukum (Siahaan, 2005:8).

2. Kewajiban Pelaku Usaha Berkaitan dengan Penjualan Daging Ayam Tidak Layak Konsumsi di Pasar Badung.

Dalam Undang-Undang 36/2009 terhadap kesehatan bahwa kesehatan hewan merupakan kondisi hewan yang tidak terkena penyakit apapun baik secara fisik maupun secara mental kemudian bisa jadi kehidupan yang produktif secara ekonomi sosial dan lain sebagainya. Ketentuan pada Pasal 7 huruf a dalam Undang-Undang inimenjelaskan bahwa pelaku usaha itu harus beretikad baik atau konsisten terhadap kegiatan usahanya kemudian konsumen wajib beretikad baik juga untuk melaksanakan pembayaran terhadap barang atau jasa yang dibelikan itu sesuai perjanjian jualbeli. Bedasarkan UU Perlindungan Konsumen bagi pelaku usaha menyatakan bahwa pelaku usaha harus beritikad baik dan tidak seenaknya menjual barang atau jasa yang tidak layak untuk dipakai oleh pembeli. Dari uraian diatas dapat merumuskan bahwa pada tahapan berlangsungnya kegiatan pelaku usaha tidak boleh cacat pikiran atau tidak boleh mengesampingkan itikad terhadap barang atau jasa pada saat dirancang untuk menjadi barang yang siap dipasarkan (Miru \& Yodo, 2008:54).

Sanksi hukum bagi Penjual barang/jasa jika benar melakukan pelanggaran terhadap aturan yang berlaku demi kelancaran usaha perdagangan daging ayam yang tidak pantas dimakan. Dalam hal ini menurut UUPK No 8/1999 yang mengatur sanksi-sanksi yang dapat menjerat pelaku usaha yang tidak menaati aturan hukum atau dengan sengaja melakukan tindakan yang merugikan pembeli yaitu:

a. Sanksi Administratif

Sesuai Pasal 60 Undang-undang Nomor 8 Tahun 1999 tentang Perlindungan Konsumen menyatakan bahwa penyelesaian sengketa konsumen berwenang memberikan sanksi administratif terhadap penjual yang melanggar Pasal 19 ayat (2) dan ayat (3) Pasal 20 Pasal 25 dan Pasal 26. Oleh karena itu sanksi administratif berupa penetapan ganti rugi paling banyak Rp. 200.000.000 (dua ratus juta rupiah) dan tata Cara penetapan sanksi administratif sebagaimana dimaksud pada pernyataan di atas diatur lebih lanjut dalam peraturan perundang-undangan.

b. Sanksi Pidana

Pasal 61 UUPK No 8/1999 menyebutkan bahwa tuntutan pidana dengan melangsungkan bagi pelaku usaha dengan pengurusnya. Rumusan pasal 62 yang ditentukan terhadap Pelanggaran-pelanggaran yang dilakukan oleh pelaku usaha diterapkan sanksi pidana dengan penjara paling lama 5 (lima) tahun atau dengan ganti rugi sebanyak dua miliar rupiah kepada pelaksana usaha yang menciptakan atau yang memublikasikan bahan yang bukan pantas dengan bobot kualitas patokan standar garansi kemanjuran komposisi begitu juga mutu dan diucapkan terhadap merek maupun amanat sama benda yang tercantum. 


\section{Upaya yang DiLakukan Badan Pengawas Obat dan Makanan Ketika Terjadi Penjualan Daging Ayam Tidak Layak Konsumsi Upaya Balai Besar POM di Denpasar dalam Pengawasan Peredaran Daging Ayam yang Tidak Layak Konsumsi}

Dari basis fungsi fundamental BPOM berpedoman pasal 68 Dekrit Presiden No 103/2001 Badan Pengawasan Obat Makanan mempunyai kewajiban:

1) Pengkajian dan penyusunan kebijakan nasional di bidang pengawasan obat dan makanan.

2) Pelaksanaan kebijakan tertentu di bidang pengawasan obat dan makanan

3) Koordinasi kegiatan fungsional dalam pelaksanaan tugas Badan Pengawas Obat dan Makanan.

4) Pemantauan pemberian bimbingan dan pembinaan terhadap kegiatan instansi pemerintah di bidang pengawasan obat dan makanan.

5) Melaksanakan pembimbing dan pertolongan tata usaha umum di bagian perancang umum ketatausahaan organisasi dan tata laksana kepegawaian keuangan berkas-berkas persandian perabotan dan rumah tangga.

Upaya balai besar POM di Denpasar dalam melindungi konsumen terkait dengan pangan daging ayam yang tidak layak konsumsi tidak hanya terbatas penerapan Post Market dan Pre Market. Berdasarkan wawancara dengan Made Ery Bahari Hantana Kepala Seksi Lapangan informasi konsumen Balai Besar POM di Denpasar pada tanggal 16 Januari 2017 disebutkan bahwa Balai Besar POM di Denpasar telah menerapkan program pasar aman dari baha $\mathrm{n}$ berbahaya dan pastinya akan sangat membantu dalam melindungi konsumen dari bahan pangan yang berbahaya dan dapat merugikan konsumen khususnya di pasar tradisional berikut data tabel hasil pemeriksaan sarana produksi sediaan farmasi dan makanan menurut kabupaten kota denpasar tahun 2018.

Balai Besar Badan Obat dan Makanan (BPOM) yaitu sebagai lembaga yang memiliki wewenang dalam hal mengawasi serta melakukan sosialisasi terhadap makanan yang mengandung zat-zat berbahaya Balai Besar POM merupakan lembaga yang sangat berpengaruh dalam usaha mengoptimalkan kebutuhan gizi masyarakat sehingga dapat merealisasikan kehidupan manusia yang berkualitas. Balai Besar POM dibentuk oleh pemerintah berdasarkan Keputusan Presiden Nomor 166 Tahun 2000 dan Nomor 103 Tahun 2001 Badan pengawasan Obat dan Makanan atau sering disingkat menjadi BPOM bertugas di bidang pengawasan obat dan makanan dengan kewenangannya antara lain pemberian izin dan pengawasan peredaran obat serta pengawasan instrument farmasi.

Dalam Pasal 58 Undang-Undang Republik Indonesia Nomor 18 Tahun 2009 ayat 1 menyebutkan dalam rangka menjamin produk hewan yang aman sehat utuh dan halal Pemerintah dan Pemerintah Daerah sesuai kewenangannya melaksanakan pengawasan pemeriksaan pengujian standardisasi sertifikasi dan registrasi produk hewan. Pada ayat 2 disebutkan pengawasan dan pemeriksaan produk hewan berturut -turut dilakukan di tempat produksi pada waktu pemotongan penampungan dan pengumpulan pada waktu dalam keadaan segar sebelum pengawetan dan pada waktu peredaran setelah pengawetan.

\section{SIMPULAN DAN SARAN}

\section{Simpulan}

Berdasarkan uraian dan pembahasan serta analisis yang telah dipaparkan diatas maka simpulan dalam penelitian ini adalah sebagai berikut.

1) Perlindungan hukum terhadap konsumen dalam hal terjadinya penjualan daging ayam yang tidak layak konsumsi di pasar Badung sudah diatur dalam Undang-undang Nomor 8 Tahun 1999 tentang Perlindungan Konsumen. Namun, berdasarkan data di lapangan konsumen banyak yang tidak mengetahui perlindungan hukum yang ada dikarenakan minimnya pengetahuan dan wawasan konsumen terkait dengan perlindungan hukum yang mereka miliki sehingga menyebabkan konsumen selalu dirugikan dengan tindakan pelaku usaha yang tidak pernah memberikan informasi yang benar jelas dan jujur sehingga konsumen tidak mendapatkan hak-haknya yang sudah diatur pada Pasal 4 huruf c Undang-undang Nomor 8 Tahun 1999 tentang Perlindungan Konsumen. Hak atas informasi yang benar jelas dan jujur mengenai kondisi dan jaminan barang dan/atau jasa. 
2) Upaya yang dapat dilakukan Badan Pengawas Obat dan Makanan (BPOM) dalam hal terjadinya penjualan daging ayam yang tidak layak konsumsi adalah dengan cara melakukan inspeksi ke lapangan serta memberikan informasi dan edukasi langsung kepada konsumen dan pelaku usaha sehingga konsumen dan pelaku usaha lebih mengetahui jenisjenis daging ayam tidak layak untuk di perdagangkan dan/atau di konsumsi oleh konsumen. Hal tersebut sudah sesuai dengan tugas dan fungsi BPOM yang diatur pada Pasal 3 huruf d peraturan kepala badan pengawas obat dan makanan Republik Indonesia nomor 14 tahun 2014 tentang organisasi dan tata kerja unit pelaksanaan teknis di lingkungan badan pengawas obat dan makanan.Pelaksanaan pemeriksaan setempat pengambilan contoh dan pemeriksaan sarana produksi dan distribusi Dan pada Pasal 3 huruf g peraturan kepala badan pengawas obat dan makanan Republik Indonesia nomor 14 Tahun 2014 tentang organisasi dan tata kerja unit pelaksanaan teknis di lingkungan badan pengawas obat dan makanan. Pelaksanaan kegiatan layanan informasi konsumen.

\section{Saran}

Melalui penelitian ini diharapkan kepada bagi konsumen harus lebih selektif dalam memilih pangan daging ayam yang layak dan/atau tidak layak untuk di konsumsi. Serta harus lebih memahami terkait hak-hak yang dimilikinya sebagai konsumen. Sehingga konsumen harus mempela jari dengan baik mengenai hak-hak yang mereka peroleh berdasarkan peraturan perundang-undangan yang berlaku agar terhindar dari kerugian-kerugian yang tidak diinginkan. Kemudian, bagi pelaku usaha wajib mempelajari dengan baik terkait dengan pangan daging ayam yang layak dan/atau tidak layak untuk dikonsumsi serta harus lebih terbuka kepada konsumen mengenai kualitas daging ayam yang dijualnya agar terciptanya hubungan yang baik yang berkelanjutan antara pelaku usaha dengan konsumen. Terakhir, bagi Badan Pengawas Obat dan Maka nan (BPOM) diharapkan untuk lebih rutin melakukan inspeksi ke lapangan dalam hal pengawasan pemberian edukasi dan informasi kepada konsumen dan pelaku usaha Badan Pengawas Obat dan Makanan (BPOM) juga diharapkan membawa sampel dan jenis daging yang layak dan/atau tidak untuk di konsumsi dalam setiap melakukan inspeksi ke lapangan agar konsumen dan pelaku usaha menjadi jauh lebih mengetahui jenis daging ayam dan/atau tidak untuk dikonsumsi sesuai dengan ketentuan-ketentuan yang baik dan benar.

\section{DAFTAR PUSTAKA}

Amirrudin, \& Asikin, Z. (2012). Pengantar Metode Penelitian hukum,. Jakarta: PT. Raja Grafindo Persada.

Barkatullah, A. H., \& Djumadi. (2018). Does self-regulation provide legal protection and security to e-commerce consumers? Electronic Commerce Research and Applications, 30, 94-101.

Kamilaris, A., Fonts, A., \& Prenafeta-Boldó, F. X. (2019). The rise of blockchain technology in agriculture and food supply chains. Trends in Food Science and Technology, 91(May 2018), 640-652.

Miru, A., \& Yodo, S. (2008). Hukum Perlindungan Konsumen. Jakarta: Raja Wali Pres.

Pham, H. V., \& Dinh, T. L. (2020). The Vietnam's food control system: Achievements and remaining issues. Food Control, 108(August 2019), 106862.

Rahardjo, S. (1980). Hukum dan Masyarakat. Bandung: Angkasa.

Ramadhan, W., \& Umar, F. (2016). Perlindungan Hukum Bagi Konsumen Atas Peredaran Daging Ayam Di Tingkat Pasar Tradisional (Studi Pada Kantor Dinas Peternakan Kabupaten Bone). Jurnal Tomalebbi, III(4), 169-184. Retrieved from Sasongko, W. (2005). Asas Perlindungan Konsumen. Lampung: Dewayter.

Siahaan, N. H. . (2005). Hukum Perlindungan Konsumen. Jakarta: Panta Rei.

Sunyoto, D. (2018). Pemasaran dan Perilaku Konsumen. Jakarta: Caps Publishing.

Susanto, H. (2008). Hak-Hak Konsumen Jika Dirugikan. Jakarta: Visimedia.

Torrico, D. D., Hutchings, S. C., Ha, M., Bittner, E. P., Fuentes, S., Warner, R. D., \& Dunshea, F. R. (2018). Novel techniques to understand consumer responses towards food products: A review with a focus on meat. Meat Science, 144(February), 30-42.

Wansink, B. (2004). Consumer Reactions to Food Safety Crises. Advances in Food and Nutrition Research, 48, 103-150. 
Zhang, M., Li, L., \& Bai, J. (2020). Consumer acceptance of cultured meat in urban areas of three cities in China. Food Control, 118(January), 107390.

Undang-Undang Dasar RI Tahun 1945

UURI Nomor 8 Tahun 1999 Tentang Perlindungan Konsumen Undang

UU RI Nomor 18 Tahun 2012 Terkait Pangan Dan Sumber Hayati

UU RI Undang Nomor 36 Tahun 2009 Terkait Kesehatan

UU RI Peraturan BPOM No. 26 Tahun 2017 Terkait Organisasi Dan Tata Kerja

Badan Pengawas Obat Dan Makanan. 